\title{
Comparative Life Cycle Assessment of HTC Concepts Valorizing Sewage Sludge for Energetic and Agricultural Use
}

\author{
Kathleen Meisel ${ }^{1, *}$, Andreas Clemens ${ }^{1}$, Christoph Fühner ${ }^{2}$, Marc Breulmann ${ }^{2}$, Stefan Majer ${ }^{1}$ (i) \\ and Daniela Thrän ${ }^{1,3}$ \\ 1 Deutsches Biomasseforschungszentrum Gemeinnützige GmbH (DBFZ), Bioenergy Systems Department, \\ Torgauer Straße 116, 04347 Leipzig, Germany; andreas.clemens@tiptop-elbe.de (A.C.); \\ stefan.majer@dbfz.de (S.M.); daniela.thraen@ufz.de (D.T.) \\ 2 Helmholtz Centre for Environmental Research (UFZ), Environmental and Biotechnology Centre, \\ Permoserstraße 15, 04318 Leipzig, Germany; chr.fuehner@gmail.com (C.F.); marc.breulmann@ufz.de (M.B.) \\ 3 Helmholtz Centre for Environmental Research (UFZ), Department of Bioenergy, Permoserstraße 15, \\ 04318 Leipzig, Germany \\ * Correspondence: kathleen.meisel@dbfz.de; Tel.: +49-341-2434-472
}

Received: 15 January 2019; Accepted: 20 February 2019; Published: 26 February 2019

\begin{abstract}
In many countries, sewage sludge is directly used for energy and agricultural purposes after dewatering or digestion and dewatering. In recent years, there has been a growing interest in additional upstream hydrothermal carbonization (HTC), which could lead to higher yields in the energetic and agricultural use. Twelve energetic and agricultural valorization concepts of sewage sludge are defined and assessed for Germany to investigate whether the integration of HTC will have a positive effect on the greenhouse gas (GHG) emissions. The study shows that the higher expenses within the HTC process cannot be compensated by additional energy production and agricultural yields. However, the optimization of the HTC process chain through integrated sewage sludge digestion and process water recirculation leads to significant reductions in GHG emissions of the HTC concepts. Subsequently, nearly the same results can be achieved when compared to the direct energetic use of sewage sludge; in the agricultural valorization, the optimized HTC concept would be even the best concept if the direct use of sewage sludge will no longer be permitted in Germany from 2029/2032. Nevertheless, the agricultural valorization concepts are not generally advantageous when compared to the energetic valorization concepts, as it is shown for two concepts.
\end{abstract}

Keywords: hydrothermal carbonization (HTC); life cycle assessment (LCA); sewage sludge; electricity and heat production; agricultural yield

\section{Introduction}

Sewage sludge is a by-product of wastewater treatment and it is produced in increasing quantities worldwide. 1.8 Mio. Mg dry matter of sewage sludge from municipal sewage treatment plants is produced in Germany, per year. Of this, $59.8 \mathrm{wt} \%$ is incinerated in coal-fired power plants and mono-combustion plants. $40.2 \mathrm{wt} \%$ is used in agriculture and landscaping [1]. In the case of energetic use, electricity and heat are generated, which predominantly substitute fossil energy in the German electricity and heating mix. Applying sewage sludge in agriculture can replace synthetically produced mineral fertilizers, which mostly rely on fossil-derived energy. Thus, both applications have the potential to contribute to climate protection.

For several years, there have been attempts to make sewage sludge treatment more efficient while using the Hydrothermal Carbonization (HTC) process. HTC is a thermochemical process that 
converts biomass into a solid product (hydrochar) at reaction conditions of 180 to $250{ }^{\circ} \mathrm{C}, 10$ to $40 \mathrm{bar}$, and a $\mathrm{pH}$ of 3 to 7 . One characteristic of HTC is that the conversion process takes place in a liquid, aqueous phase [2,3]. This means that wet, biogenic residues, such as biogenic municipal waste [4-7], fermentation residues [8,9], waste from agriculture and the food industry [10-15], as well as mechanically dehydrated sewage sludge with a water content of $75 \mathrm{wt} \%$ are particularly suitable as HTC feedstocks [16-18]. Like sewage sludge, hydrochars that are produced during HTC can be used for energy and agricultural purposes. For energetic use, the fact that hydrochar is easier to dewater when compared to the untreated sewage sludge is of particular importance. This positive effect has been extensively studied and it is described in [19-23]. For agricultural use, the hydrochar incorporation into soil is intended to improve plant growth and thus achieve higher crop yields. The soil-related use of hydrochar and its impact on plant growth have been described, among others, in [15,24-34].

In addition, the HTC of residue, waste, and biomass flows, such as green waste [6], olive mill waste [35], food wastes [36], biomass waste streams [37,38], and algae [39] has already been assessed several times by means of life cycle assessment (LCA). However, publications on HTC's LCA of sewage sludge are scarce. The HTC of bio-wastes, including sewage sludge, was investigated in [40]. Here, the focus was on energetic utilization in the form of fuel gas and diesel oil. In [41], different sewage sludge management methods were compared. The hydrothermal pyrolysis is one option investigated. The integration of HTC into an energetic utilization chain of sewage sludge is investigated in [42]. A comparative life cycle assessment, which includes the use of both sewage sludge and hydrochar, in energetic as well as agricultural applications, has not yet been conducted, to our knowledge.

In our study, while taking into account the processes of HTC with and without sewage sludge digestion as well as energetic and agricultural utilization, twelve different valorization concepts of sewage sludge are examined based on empirical and literature data. The aim is to identify the most promising concept from a greenhouse gas (GHG) perspective. In addition, it shall be determined (i) whether the integration of HTC with and without digestion in sewage sludge valorization concepts is more advantageous when compared to a direct utilization of sewage sludge and (ii) whether an energetic or an agricultural valorization is more favorable regarding their global warming potential.

\section{Materials and Methods}

\subsection{Concept Definition}

Twelve different valorizing concepts of sewage sludge are defined in this study; six with an agricultural use and six with an energetic use. Since there are sewage treatment plants with and without digestion of sewage sludge, both of the versions are considered in the concepts. To investigate whether the hydrothermal carbonization of sewage sludge offers advantages in comparison with direct agricultural or energetic use (as is mostly the case for Germany), the twelve concepts include both the direct use of sewage sludge (SS) after dewatering or digestion and dewatering and the use of hydrothermally carbonized sewage sludge (hydrochar). In the concepts of hydrothermal carbonization, the HTC process parameters are varied. In the first case (HTC 1), the HTC process runs at $170{ }^{\circ} \mathrm{C}$ and a residence time of $2 \mathrm{~h}$, while in the second case (HTC 2), a temperature of $210^{\circ} \mathrm{C}$ and a residence time of $10 \mathrm{~h}$ are chosen. The key characteristics of the concepts are also summarized in Table 1. Figure 1 shows an overview of the process concepts that were defined. 
Table 1. Key characteristics of twelve valorization concepts investigated.

\begin{tabular}{lccc}
\hline Process Chain & HTC Process Parameters & Agricultural Use & Energetic Use \\
\hline SS without sludge digestion & - & A-SS & E-SS \\
SS with sludge digestion & - & A-D+SS & E-D+SS \\
HTC 1 without sludge digestion & $170{ }^{\circ} \mathrm{C}, 2 \mathrm{~h}$ & A-HTC 1 & E-HTC 1 \\
HTC 2 without sludge digestion & $210^{\circ} \mathrm{C}, 10 \mathrm{~h}$ & A-HTC 2 & E-HTC 2 \\
HTC 1 with sludge digestion & $170{ }^{\circ} \mathrm{C}, 2 \mathrm{~h}$ & A-D+HTC 1 & E-D+HTC 1 \\
HTC 1 with sludge digestion \& & $170^{\circ} \mathrm{C}, 2 \mathrm{~h}$ & A-D+HTC 1+RP & E-D+HTC 1+RP \\
recirculation of process water & & & \\
\hline
\end{tabular}

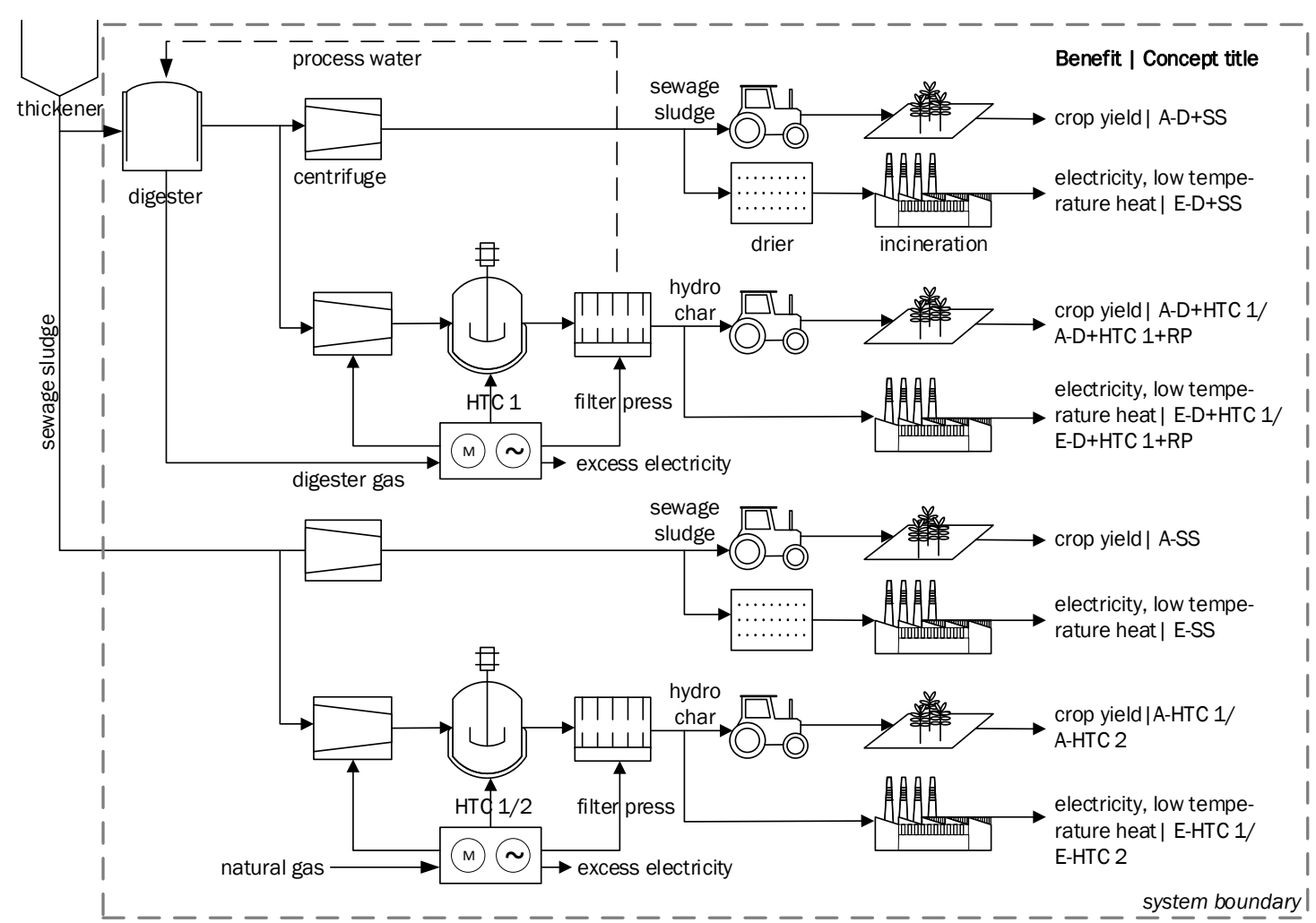

Figure 1. Overview of the valorization concepts investigated.

Since both options, with and without sewage sludge digestion, are considered, and all of the concepts shall be based on the same input material flow, the system boundary is defined after the thickener of the sewage treatment plant. The sewage sludge is assumed to leave the static thickener with a dry matter (DM) content of $5 \mathrm{wt} \%$. The amount of sewage sludge is sized according to the capacity of an industrial HTC plant, set at $14,000 \mathrm{Mg} \mathrm{a}^{-1}$, with a DM content of $25 \mathrm{wt} \%$. This corresponds to a DM of $3500 \mathrm{Mg} \mathrm{a}^{-1}$ and thus to a quantity of sewage sludge from a size class 5 municipal sewage plant amounting to approximately 127,500 population equivalents (PEs). Thus, at DM content of $5 \mathrm{wt} \%$, the amount of sewage sludge after the static thickener is $70,000 \mathrm{Mg} \mathrm{a}^{-1}$.

The A-SS concept corresponds to the direct agricultural use of the non-anaerobically stabilized sewage sludge from the sewage treatment plant. The sewage sludge entering the system boundary is dewatered in a centrifuge to a DM content of $25 \mathrm{wt} \%$. The centrate leaves the system boundary and it is returned to the sewage treatment plant, where it is mechanically, biologically, and chemically treated. The expenses for the wastewater treatment are included in all of the valorization concepts. The dewatered sewage sludge is transported to the field and then applied there. The effects of sewage sludge and hydrochar on plant growth were investigated by the cultivation of mustard (Sinapis alba L.), winter rye (Secale cereale L.), and corn (Zea mays L.) on a poor sandy site in Brandenburg (Germany). Starting the field trials with mustard in August 2014, already harvesting winter rye in May 2015 and 
cultivating corn in the summer of 2015, this rotation allowed for the cultivation of three crop species within only 12 months. The resulting yields leaves the system boundary as a benefit of the agricultural valorization concepts. Expenses that are required in the field, such as the seeds, pesticides, and diesel for agricultural machinery, are taken into account in the agricultural concepts. In the case of the concepts A-HTC 1 and A-HTC 2, a HTC plant is integrated into the process chain after the centrifuge. The sewage sludge, dewatered to $25 \mathrm{wt} \%$ of DM, is hydrothermally carbonized in the HTC plant and then dewatered in a filter press. The dewatered hydrochar has a DM content of $45.5 \mathrm{wt} \%$ (A-HTC 1 ) and $54.2 \mathrm{wt} \%$ (A-HTC 2), respectively. The filtrate leaves the system boundary with a DM content of $1.8 \mathrm{wt} \%$ (particle $>45 \mu \mathrm{m}$ ) and it is returned to the sewage treatment plant, where it is analogously cleaned to the centrate in the A-SS concept. A natural gas based combined heat and power (CHP) plant provides the HTC system with the required high-temperature heat and the auxiliary equipment with electricity. The excess electricity leaves the system boundary as a benefit. It is assumed that the excess heat cannot be further used. The hydrochar that is produced is transported to the field and applied to the soil. The two concepts, A-HTC 1 and A-HTC 2, only differ in terms of the parameters used in the HTC process (cf. Table 1).

In contrast to the concept A-SS, the concept A-D+SS integrates the anaerobic stabilization of the sewage sludge (digestion of sewage sludge) into the process chain. The incoming sewage sludge is anaerobically stabilized in the digester. Subsequently, the sewage sludge is dewatered in a centrifuge to a DM content of $25 \mathrm{wt} \%$. Analogous to A-SS, the centrate is returned to the sewage treatment plant, where it is cleaned. The anaerobically stabilized and dewatered sewage sludge is transported to the field and then applied to the soil. Based on the concept A-D+SS, concepts A-D+HTC 1 and A-D+HTC $1+R P$ are defined. In both concepts, a HTC plant is integrated into the process chain after the centrifuge. The sewage sludge, dewatered to $25 \mathrm{wt} \%$ of DM, is hydrothermally carbonized in the HTC plant and then dewatered in a filter press. The hydrochar produced is again transported to the field and then applied to the soil. Both of the concepts differ only in the cleaning of the HTC process water. In A-D+HTC 1, the HTC process water leaves the system boundary and it is returned to the sewage treatment plant. In contrast, in A-D+HTC 1+PR the HTC process water is directed to the digester within the system boundary and anaerobically treated there. Consequently, more digester gas is produced when compared with the other concepts, including sludge digestion. The concept A-D+HTC $1+\mathrm{PR}$ represents an optimized HTC concept. In the valorization concepts, including the sewage sludge digestion (A-D-SS, A-D+HTC 1, A-D-HTC 1+PR), the digester gas is fed to a CHP unit in order to produce heat and electricity. The CHP unit supplies the HTC plant with high-temperature heat and the digester with low-temperature heat. It is also assumed that the excess heat is not further used at the site of the sewage treatment plant and it leaves the system boundary as a loss. The electricity from the CHP unit supplies the electrical equipment. Excess electricity leaves the system boundary as a benefit.

The agricultural concepts are compared with corresponding energetic concepts. In this case, the sewage sludge or hydrochar are used to generate energy in a mono-combustion plant. According to [43], a lower heating value (LHV) of $4.5 \mathrm{MJ} \mathrm{kg}^{-1}$ is required for autothermal combustion in the mono-combustion plant. For this reason, to directly combust the sewage sludge, the sludge has to be dried thermally in a drier. This is done at the site of the mono-combustion plant, using the heat supplied from the mono-combustion plant. The condensate leaves the system boundary and then has to be cleaned. As already mentioned, the wastewater treatment is taken into account in the balancing. In contrast, the LHV of the hydrochar, which is mechanically dewatered in the filter press, is higher than $4.5 \mathrm{MJ} \mathrm{kg}^{-1}$. This means that the HTC concepts do not need a thermal drier. In all energetic valorization concepts, the use of natural gas for the auxiliary firing, the use of an adsorbent (sodium hydrogen carbonate) for gas purification, and the disposal of the resulting ash are considered within the GHG assessment. A recycling of phosphorus and heavy metals from ashes is not considered. It is assumed that the excess heat that is produced from mono-combustion can be further used for other purposes or processes. Thus, the benefits of the energetic valorization concepts are electricity and low-temperature heat. 


\subsection{Calculation of GHG Emissions}

To calculate and compare the GHG emissions of all the valorization concepts investigated, the life cycle assessment methodology according to the ISO guidelines 14040 and 14044 is applied [44,45]. Due to its bioenergy context, DIN ISO 13065 is also applied [46].

For this study, only the global warming potential (GWP 100), as expressed in $\mathrm{CO}_{2}$ equivalents, is calculated as one of many possible environmental impact categories within the LCA framework. The characterization factors from the International Panel on Climate Change (IPCC) 2007 are used to convert all potential GHG emissions into the common unit of $\mathrm{CO}_{2}$ equivalents [47]. Assuming that the sewage sludge consists entirely of biogenic material, the biogenic $\mathrm{CO}_{2}$ emissions that were released during the combustion of the sewage sludge or hydrochar are considered to be climate-neutral in the energetic valorization concepts $[48,49]$. The same applies to the digester gas, which is incinerated in the CHP unit to provide the energy for the HTC process within the concepts with sludge digestion. In contrast, the direct carbon dioxide emissions from the combustion of natural gas in the CHP plant and in the mono-combustion plant (auxiliary firing) are included in the GHG balance.

In all of the valorization concepts, the main benefit is the disposal of sewage sludge. According to the German Institute for Standardization, the GHG emissions of concepts cannot be directly compared in order to identify the most favorable valorization concept, since they differ in their additional benefits (see Table 2) [44-46]. In the agricultural valorization concepts, agricultural yields are achieved, whereas in the energetic valorization concepts, electricity and heat are produced. This multifunctional problem can be addressed by means of different approaches [50-55]. In this study, each valorization concept is compared with its corresponding "substituted" reference system. To create these reference concepts, reference products, which fulfil the same benefits as the products in the corresponding valorization concept and may potentially be replaced by them, have to be identified. Within this substitution methodology, the choice of the "right" replaced production is decisive in fulfilling the adequate benefit $[55,56]$.

Table 2. Main and additional benefits in the valorization and reference concepts; creation of equivalent benefits.

\begin{tabular}{|c|c|c|}
\hline & Valorization Concepts & Reference Concepts \\
\hline \multicolumn{3}{|c|}{ Agricultural Use } \\
\hline Benefit & $\begin{array}{l}\text { - } \\
\text { 70,000 } \mathrm{Mg} \mathrm{a}^{-1} \text { of sewage sludge disposed } \\
\text { of on the field } \\
\text { - Mustard, rye, corn yield applying sludge } \\
\text { and hydrochar } \\
\text { - } \quad \text { Excess electricity in HTC concepts }\end{array}$ & $\begin{array}{l}\text { - } \quad \begin{array}{l}70,000 \mathrm{Mg} \mathrm{a}^{-1} \text { of sewage sludge } \\
\text { disposed of via co-combustion }\end{array} \\
\text { - } \quad \text { Adequate mustard, rye, corn yield } \\
\text { through mineral N fertilization } \\
\text { - } \quad \begin{array}{l}\text { Electricity and low-temperature heat } \\
\text { from co-combustion }\end{array}\end{array}$ \\
\hline Credits for & $\begin{array}{l}\text { Excess electricity from combined heat and } \\
\text { power }(\mathrm{CHP}) \text { unit at the HTC plant }\end{array}$ & $\begin{array}{l}\text { - Electricity and low-temperature heat } \\
\text { from co-combustion }\end{array}$ \\
\hline \multicolumn{3}{|c|}{ Energetic Use } \\
\hline Benefit & $\begin{array}{l}\text { - } \\
\text { 70,000 } \mathrm{Mg} \mathrm{a}^{-1} \text { of sewage sludge disposed } \\
\text { of via mono-combustion } \\
\text { - Electricity and low-temperature heat } \\
\text { from mono-combustion } \\
\text { - } \quad \text { Excess electricity in HTC concepts }\end{array}$ & 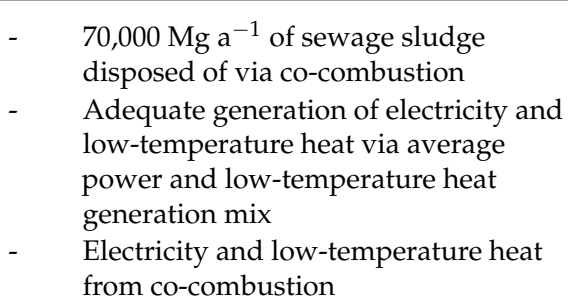 \\
\hline Credits for & $\begin{array}{l}\text { None; excess electricity from CHP plant is } \\
\text { added as a benefit to electricity production } \\
\text { from mono-combustion }\end{array}$ & $\begin{array}{l}\text { - Electricity and low-temperature heat } \\
\text { from co-combustion }\end{array}$ \\
\hline
\end{tabular}


In this study, the currently predominant conventional production is taken as reference production (see Table 2). The predominant conventional disposal of sewage sludge is its co-combustion in a power plant [1]. The expenses of co-combustion, such as dewatering of sewage sludge, ash disposal, and cleaning of the flue gas are therefore included in all of the reference concepts as adequate disposal of sewage sludge. During the co-combustion, electricity and heat are generated as an additional benefit in the reference concepts.

The benefit of the mustard, winter rye, and corn yields achieved in the agricultural valorization concepts is conventionally produced by mineral $\mathrm{N}$-fertilization in the reference concepts. The electricity and low-temperature heat that are generated by the mono-combustion in the energy valorization concepts are assumed to replace the conventional German power and low-temperature generation mix in the corresponding reference concept.

To ensure that, as required in $[44-46,57]$, the valorization and reference concepts have equivalent benefits, the products in the reference concepts have to fulfill the same benefits to the same extent and in the same quality as the products in the valorization concepts, but in a conventional manner. The substitution method is used to compensate for the differences in the benefits between the valorization and the reference concepts. Thus, all of the reference concepts get a GHG credit for the amount of electricity and heat generated by co-combustion (see Table 2). The same applies to the amount of excess electricity that is generated in the CHP process at the HTC plant in the valorization concepts. In the energetic valorization concepts, however, this amount of electricity is internally added as a benefit to the electricity that was generated by mono-combustion.

After creating equal benefits in the valorization and reference concepts, the GHG emissions are assessed for all concepts. In a next step, the GHG emissions from each valorization concept are subtracted from those from its corresponding reference concept to calculate the GHG saving that is associated with the potential substitution of each reference concept. Since all of the valorization concepts have the same annual input of $70,000 \mathrm{Mg} \mathrm{a}^{-1}$ of sewage sludge, the respective GHG savings, expressed in absolute figures in tones of $\mathrm{CO}_{2}$ equivalents per year, can be compared and ranked. The valorization concept potentially causing the highest GHG saving as compared to its corresponding reference concept is the best concept from a global warming perspective.

\subsection{Data and Assumptions}

The characteristics of the sewage sludge and the produced hydrochars to be valorized in the concepts are shown in Table 3. The mass and energy balances for all concepts shown in Figure 1 are calculated within the defined system boundaries. These are listed in Tables 4-7. Efficiencies and further technical data for the processing units are taken from literature. The electrical efficiency of the natural gas CHP unit used in the HTC concepts is 38\% [58], while that of the digester gas CHP unit is $30 \%$ [59]. Data from the HTC process comes both from the HTC reactor at a large-scale facility and from literature. The electrical efficiency and the fuel utilization rate of the mono-combustion are assumed to be $15 \%$ and $90 \%$, respectively [60]. The co-combustion within the reference concepts is assumed to take place with an electrical efficiency of $42 \%$ and a fuel utilization rate of $44 \%$ [61]. The flows of the ash and flue gas from the mono- and co-combustion are taken from the energetic modelling of the combustion process. 
Table 3. Characteristics of the sewage sludge and the hydrochars $(\mathrm{wf}=$ water free; waf = water and ash free).

\begin{tabular}{lcccc}
\hline \multicolumn{1}{c}{ Parameter } & Unit & Sewage Suldge & Hydrochar HTC 1 & Hydrochar HTC 2 \\
\hline Dry matter & $\mathrm{wt}^{\circ}$ & 25.0 & 45.5 & 54.2 \\
LHV & $\mathrm{MJ} \mathrm{kg}^{-1}$ & 11.64 & 11.63 & 13.58 \\
Ash content & $\mathrm{wt}_{\mathrm{wf}}$ & 45.9 & 48.8 & 51.5 \\
Elemental analysis & & & & \\
$\mathrm{C}$ & $\mathrm{wt} \%_{\text {waf }}$ & 51.8 & 55.3 & 63.7 \\
$\mathrm{H}$ & $\mathrm{wt} \%_{\text {waf }}$ & 7.1 & 7.0 & 8.0 \\
$\mathrm{~S}$ & $\mathrm{wt} \%_{\text {waf }}$ & 1.8 & 3.8 & 4.4 \\
$\mathrm{~N}$ & $\mathrm{wt} \%_{\text {waf }}$ & 7.5 & 7.8 & 6.6 \\
\hline
\end{tabular}

Table 4. Overview of material balances of concepts for agricultural use.

\begin{tabular}{|c|c|c|c|c|c|c|c|}
\hline \multirow[t]{2}{*}{ Parameter } & \multirow[t]{2}{*}{ Unit } & \multicolumn{3}{|c|}{ Without Digestion } & \multicolumn{3}{|c|}{ With Digestion } \\
\hline & & A-SS & A-HTC 1 & A-HTC 2 & A-D+SS & $\begin{array}{c}\text { A-D+ } \\
\text { HTC } 1\end{array}$ & $\begin{array}{c}\text { A-D }+ \text { HTC } 1+ \\
\text { PR }\end{array}$ \\
\hline \multicolumn{8}{|l|}{ Input } \\
\hline Sewage sludge & $\mathrm{Mga}^{-1}$ & 70,000 & 70,000 & 70,000 & 70,000 & 70,000 & 70,000 \\
\hline Sulfuric acid & $\mathrm{Mg} \mathrm{a}^{-1}$ & - & 112 & 213 & - & 82 & 85 \\
\hline Natural gas CHP plant & $\mathrm{Mga}^{-1}$ & - & 461 & 494 & - & - & - \\
\hline Seed & $\mathrm{Mg} \mathrm{a}^{-1}$ & 114 & 60 & 59 & 114 & 60 & 66 \\
\hline Pesticides & $\mathrm{Mg} \mathrm{a}^{-1}$ & 6 & 3 & 3 & 6 & 3 & 4 \\
\hline Diesel & $\mathrm{Mg} \mathrm{a}^{-1}$ & 87 & 46 & 45 & 87 & 46 & 51 \\
\hline \multicolumn{8}{|l|}{ Output } \\
\hline Mustard yield & $\mathrm{Mg} \mathrm{a}^{-1}$ & 1872 & 888 & 793 & 1869 & 887 & 981 \\
\hline Winter rye yield & $\mathrm{Mg} \mathrm{a}^{-1}$ & 1804 & 945 & 902 & 1801 & 944 & 1044 \\
\hline Corn yield & $\mathrm{Mg} \mathrm{a}^{-1}$ & 7380 & 3657 & 3847 & 7369 & 3652 & 4040 \\
\hline Centrate & $\mathrm{Mg} \mathrm{a}^{-1}$ & 56,045 & 56,045 & 56,045 & 59,009 & 59,009 & 65,549 \\
\hline HTC process water & $\mathrm{Mg} \mathrm{a}^{-1}$ & - & 9321 & 10,147 & - & 6786 & - \\
\hline Exhaust gas $\mathrm{CHP}$ plant $\mathrm{CO}_{2}{ }^{*}$ & $\mathrm{Mg} \mathrm{a}^{-1}$ & - & 1249 & 1338 & - & - & - \\
\hline
\end{tabular}

${ }^{*}$ Fossil $\mathrm{CO}_{2}$ from the combustion of natural gas in the $\mathrm{CHP}$ plant.

Table 5. Overview of material balances of concepts for energetic use.

\begin{tabular}{|c|c|c|c|c|c|c|c|}
\hline \multirow[t]{2}{*}{ Parameter } & \multirow[t]{2}{*}{ Unit } & \multicolumn{3}{|c|}{ Without Digestion } & \multicolumn{3}{|c|}{ With Digestion } \\
\hline & & E-SS & E-HTC 1 & E-HTC 2 & E-D+SS & $\begin{array}{c}\text { E-D+ } \\
\text { HTC } 1\end{array}$ & $\begin{array}{c}\text { E-D+ HTC } \\
1+\text { PR }\end{array}$ \\
\hline \multicolumn{8}{|l|}{ Input } \\
\hline Sewage sludge & $\mathrm{Mga}^{-1}$ & 70,000 & 70,000 & 70,000 & 70,000 & 70,000 & 70,000 \\
\hline Sulfuric acid & $\mathrm{Mga}^{-1}$ & - & 112 & 213 & - & 82 & 85 \\
\hline Natural gas CHP plant & $\mathrm{Mga}^{-1}$ & - & 461 & 494 & - & - & - \\
\hline Natural gas auxiliary burner & $\mathrm{Mga}^{-1}$ & 2 & 1 & 1 & 1 & 1 & 1 \\
\hline Adsorbent gas cleaning & $\mathrm{Mg} \mathrm{a}^{-1}$ & 223 & 244 & 263 & 136 & 149 & 146 \\
\hline \multicolumn{8}{|l|}{ Output } \\
\hline Centrate & $\mathrm{Mga}^{-1}$ & 56,045 & 56,045 & 56,045 & 59,009 & 59,009 & 65,549 \\
\hline HTC process water & $\mathrm{Mga}^{-1}$ & - & 9321 & 10,147 & - & 6786 & - \\
\hline Exhaust gas $\mathrm{CHP}$ plant $\mathrm{CO}_{2} *$ & $\mathrm{Mg} \mathrm{a}^{-1}$ & - & 1249 & 1338 & - & - & - \\
\hline Condensate of drier & $\mathrm{Mg} \mathrm{a}^{-1}$ & 5169 & - & - & 4714 & - & - \\
\hline Exhaust gas from mono-inc. $\mathrm{CO}_{2}{ }^{* *}$ & $\mathrm{Mg} \mathrm{a}^{-1}$ & 122 & 130 & 140 & 75 & 80 & 79 \\
\hline Ash from mono-incineration & $\mathrm{Mga}^{-1}$ & 1284 & 831 & 876 & 1209 & 749 & 813 \\
\hline
\end{tabular}

${ }^{*}$ Fossil $\mathrm{CO}_{2}$ from the combustion of natural gas in the $\mathrm{CHP}$ plant; ${ }^{* *}$ Fossil $\mathrm{CO}_{2}$ from the combustion of natural gas in the auxiliary burner of the mono-incineration unit. 
Table 6. Overview of energy balances of concepts for agricultural use.

\begin{tabular}{lccccccc}
\hline \multicolumn{1}{c}{ Parameter } & Unit & \multicolumn{3}{c}{ Without Digestion } & \multicolumn{3}{c}{ With Digestion } \\
\hline & & A-SS & A-HTC 1 & A-HTC 2 & A-D+SS & $\begin{array}{c}\text { A-D+ } \\
\text { HTC 1 }\end{array}$ & $\begin{array}{c}\text { A-D+ HTC } \\
\text { 1+ PR }\end{array}$ \\
\hline $\begin{array}{l}\text { Input } \\
\quad \text { Sewage sludge }\end{array}$ & $\mathrm{MWh} \mathrm{a}^{-1}$ & 16,235 & 16,235 & 16,235 & 16,235 & 16,235 & 16,235 \\
$\quad \mathrm{MWh} \mathrm{a}^{-1}$ & - & 6114 & 6552 & - & - & - \\
$\quad \begin{array}{l}\text { Electricity } \\
\quad \text { Output }\end{array}$ & $\mathrm{MWh} \mathrm{a}^{-1}$ & 121 & - & - & - & - & - \\
$\quad$ Electricity & $\mathrm{MWh} \mathrm{a}^{-1}$ & - & 1872 & 1531 & 1208 & 966 & 1154 \\
$\quad$ Low-temp. heat & $\mathrm{MWh} \mathrm{a}^{-1}$ & - & - & - & - & - & - \\
\hline
\end{tabular}

Table 7. Overview of energy balances of concepts for energetic use.

\begin{tabular}{|c|c|c|c|c|c|c|c|}
\hline \multirow[t]{2}{*}{ Parameter } & \multirow[t]{2}{*}{ Unit } & \multicolumn{3}{|c|}{ Without Digestion } & \multicolumn{3}{|c|}{ With Digestion } \\
\hline & & E-SS & E-HTC 1 & E-HTC 2 & E-D+SS & $\begin{array}{c}\text { E-D+ } \\
\text { HTC } 1\end{array}$ & $\begin{array}{c}\text { E-D+ HTC } \\
1+\text { PR }\end{array}$ \\
\hline \multicolumn{8}{|l|}{ Input } \\
\hline Sewage sludge & MWh $\mathrm{a}^{-1}$ & 16,235 & 16,235 & 16,235 & 16,235 & 16,235 & 16,235 \\
\hline Natural gas & MWh $\mathrm{a}^{-1}$ & 24 & 6127 & 6564 & 17 & 9 & 10 \\
\hline Electricity & MWh $\mathrm{a}^{-1}$ & 121 & - & - & - & - & - \\
\hline \multicolumn{8}{|l|}{ Output } \\
\hline Electricity & MWh $\mathrm{a}^{-1}$ & 1289 & 2816 & 2721 & 1913 & 1514 & 1685 \\
\hline Low-temp. heat & MWh $^{-1}$ & 3935 & 4718 & 5952 & 1235 & 2744 & 2654 \\
\hline
\end{tabular}

Data regarding inputs to the agricultural valorization concepts, such as seeds, pesticides, diesel, and the yields of mustard, winter rye, and corn originate from field testings on the sandy marginal trial site in Brandenburg (Germany). The same field trials also provide the data on the agricultural inputs that are necessary to achieve equivalent mustard, winter rye, and corn yields via mineral fertilization in the agricultural reference concepts.

It is assumed that, in the agricultural valorization concepts, the treated sewage sludge and hydrochar are transported $30 \mathrm{~km}$ to the field, while in the energetic valorization concepts, both are transported $100 \mathrm{~km}$ to the mono-combustion plant.

For the GHG assessment, the mass and energy balances of the different valorization concepts are each transferred to a life-cycle model using the Umberto NXT Universal 7.1.13 software [62]. The emission data for the auxiliary materials and energy that are listed in the mass and energy balances come from the ecoinvent database v2.2 and v3.3 [63,64]. The direct and indirect nitrous oxide emissions resulting from the use of the treated sewage sludge and hydrochar in the field were determined in a laboratory using 40-day incubation experiments. The direct $\mathrm{CO}_{2}$ emissions from the combustion of the natural gas in the CHP unit and the mono-combustion unit (auxiliary burner) are taken from our own balancing of the combustion process.

Creating the reference concepts, conventional co-combustion and conventional cultivation and energy generation systems are also modelled in Umberto. The emission factor that was used for the German electricity mix and low-temperature heat mix is sourced from the Gemis database v4.9 [65]. It is $0.61 \mathrm{~kg} \mathrm{CO}_{2}$-eq $\mathrm{kWh}^{-1}$ for power generation and $0.08 \mathrm{~kg} \mathrm{CO}_{2}$-eq. $\mathrm{MJ}^{-1}$ for the production of low-temperature heat [65]. These emission factors are also used to determine the credits for the additional generation of electricity and low-temperature heat.

\section{Results}

Figures 2 and 3 show clearly that only three agricultural valorization concepts (A-SS, A-D+SS, and A-D+HTC 1+PR) achieve GHG savings when compared to their corresponding conventional reference concepts. All other concepts that were investigated potentially emit more GHG emissions than their corresponding conventional reference concepts. In the concepts of direct valorization of 
sewage sludge (A-SS and A-D+SS), the applied sewage sludge contributes to achieving a relatively high yield of mustard, winter rye, and corn with low treatment expenses (dewatering or digestion and dewatering). If this yield is produced via mineral fertilizers as in the corresponding reference concepts, significantly more GHG are potentially emitted. This is mainly due to the higher GHG emissions from the production of synthetic nitrogen fertilizer when compared to the simple treatment of sewage sludge. In the agricultural valorization concepts A-HTC 1, A-HTC 2, and A-D+HTC 1, where the sewage sludge is converted to hydrochar via HTC, no GHG savings can be achieved as compared to the conventional reference systems. One reason is that the relatively high expenses of producing hydrochar in the HTC process cannot be compensated by higher yields when compared to the production system with conventional mineral fertilization.

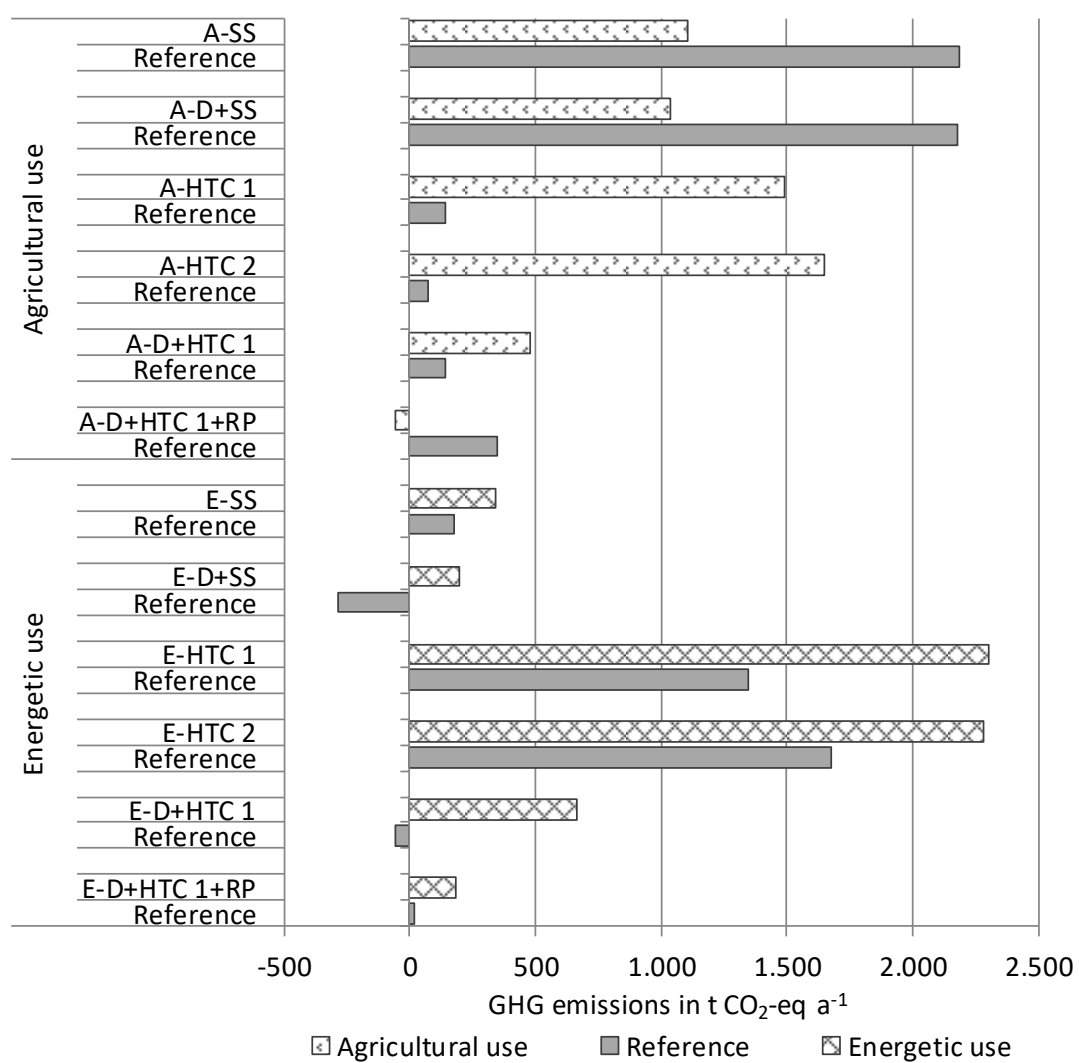

Figure 2. Greenhouse gas (GHG) emissions of valorization and reference concepts.

The other reason is that in all reference concepts of the agricultural valorization concepts, the conventional disposal of $70,000 \mathrm{Mg}$ of sewage sludge (co-combustion in a power plant) is taken into account, in addition to the conventional production of the specific yield of mustard, rye, and maize. As well as requiring relatively low expenses, this co-combustion in the coal-fired power plant has an additional benefit as electricity and heat, which is credited to the reference concepts.

Despite these relatively high credits for the reference concepts, the optimized agricultural valorization concept, including HTC (A-D+HTC 1+PR), can reduce the GHG emissions when compared with the other agricultural valorization concept, including HTC (A-HTC 1 and A-HTC 2). When the process water is recirculated to the digester, additional digester gas is generated, which is used in the $\mathrm{CHP}$ unit instead of the fossil-derived natural gas and it produces a large amount of excess electricity, which is credited within the GHG balancing. As a result, the GHG emissions from the HTC process can be significantly reduced. It is even more than climate-neutral. Nevertheless, the GHG savings from the direct agricultural use of sewage sludge (A-SS, A-D+SS) are higher than from the optimized HTC concept when compared to their reference concepts. 


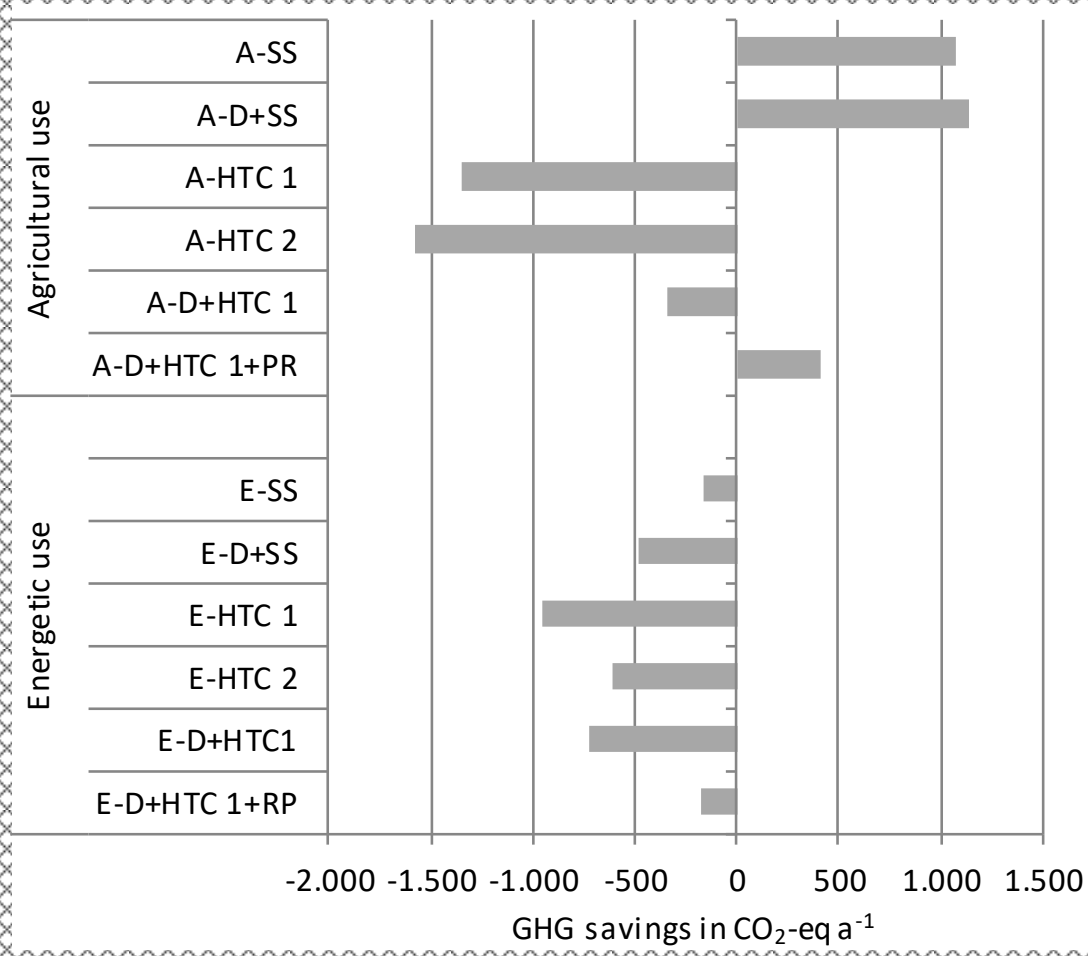

Figure 3. GHG savings comparing valorization and reference concepts.

By comparing the agricultural valorization concepts without digestion (A-SS, A-HTC1) and with digestion (A-D+SS, A-D+HTC1), it becomes clear that the concepts with digestion have potentially higher GHG saving or lower "additional GHG emissions" (see Figure 3). This is due to the generation of digester gas in the digester, which replaces the use of natural gas in the CHP unit.

Increasing the process parameters in the HTC process from $170^{\circ} \mathrm{C}$ to $210^{\circ} \mathrm{C}$ and from $2 \mathrm{~h}$ to $10 \mathrm{~h}$ residence time (A-HTC 2) leads to an increased demand for natural gas in the CHP unit but it does not adequately increase the yield of mustard, winter rye, and corn. The A-HTC 2 concept thus potentially causes more GHG emissions when compared to its reference concept than concept A-HTC 1 to its reference concept.

Figures 2 and 3 also show that all energetic valorization concepts cause more GHG emissions than their corresponding reference systems. The lowest "additional emissions" are caused by the concept of direct using the sewage sludge (E-SS), closely followed by the optimized concept with HTC, process water recirculation, and sewage sludge digestion (E-D+HTC1+PR). Both the concept E-SS and its corresponding reference system have similar expenses in the treatment of sewage sludge and monoor co-combustion. Since the reference concept generates more electricity during co-combustion due to its higher electrical efficiency when compared with the mono-combustion in the valorization concept, the higher credit leads to lower GHG emissions in the reference concept. In the energetic valorization concepts, including HTC, the combustion of higher-grade hydrochar generates more power and heat as compared to the direct combustion of sewage sludge, but the higher expenses to produce hydrochar overcompensate for this positive effect. This trend is reduced in the concept E-D+HTC $1+\mathrm{PR}$. Here, again, recirculating the process water from the HTC process into the digester leads to a reduction in GHG emissions. However, this cannot compensate for the lower electricity generation when compared with the corresponding co-combustion in the reference concept. Nevertheless, the concept E-SS has the lowest additional emissions of all the energetic valorization concepts. In contrast to agricultural valorization concepts, sewage sludge digestion has no general beneficial effect on the energetic valorization. The concept E-D+SS has higher additional emissions as compared to its reference concept than the concept E-SS. Sewage sludge digestion, and thus the use of the digester gas instead of the natural gas in the CHP unit, reduces the GHG emissions in this valorization concept. 
However, more energy, especially more heat, is generated from sewage sludge without their digestion in the mono-combustion unit. Analogous to the agricultural valorization concepts, the positive effect of sewage sludge digestion becomes clear when comparing the concepts E-HTC1 and E-D-HTC1. The reduced GHG emissions that are due to sewage sludge digestion outweigh the lower energy production in the mono-combustion.

In contrast to the agricultural valorization concepts, an increased carbonization temperature and HTC residence time (E-HTC 2) as compared to the E-HTC 1 concept leads to lower additional emissions, since the higher lower heating value of the hydrochar from the HTC 2 process leads to the generation of more electricity and heat.

Overall, the agricultural and energetic valorization concepts, including HTC, have no higher GHG savings when compared to its corresponding reference concepts than the concepts of direct use of sewage sludge. Within the agricultural valorization concepts, the optimized HTC concept A-D+HTC 1+PR potentially causes significantly less GHG saving than the concepts A-SS and A-D+SS, while, within the energetic valorization concept, the optimized HTC concept E-D+HTC 1+PR has nearly the same additional GHG emissions than E-SS as compared to their corresponding reference concepts (see Figure 3). Sewage sludge digestion, by contrast, has a positive effect on the GHG savings when compared to the reference concept, with just one exception (E-D+SS). Altogether, the agricultural valorization concept A-D+SS has the highest GHG saving, followed by A-SS and A-D+HTC 1+PR. Thus, the concept directly using the sewage sludge for agricultural purposes A-D+SS is the best concept from the global warming potential perspective. Only regarding the GHG emissions, the concept of A-D+HTC 1+PR causes the lowest GHG emissions and it is even more than climate-neural.

However, the agricultural valorization concepts are not generally advantageous when compared to the energetic valorization concepts, as in two cases (A-HTC 1 vs. E-HTC 1 and A-HTC 2 vs. E-HTC 2), the energetic valorization concepts would potentially emit less additional GHG emissions as compared to the reference concepts than the agricultural valorization concepts.

\section{Discussion}

The results show that only three of the agricultural valorization concepts can potentially achieve GHG savings when compared to their corresponding reference concepts, whereas all of the energetic valorization concepts emit more GHG emissions than their respective reference concepts. While the results of the energetic use of sewage sludge base on mass and energy balances that are derived from literature data and from a HTC reactor at a large-scale facility the mass and energy balances for the agricultural use are mainly based on data from a three-year test series (see Section 2.3) on sandy marginal revenue sites in Germany. Thus, the statements on GHG emissions and GHG savings of the agricultural valorization concepts, as well as the statements on the comparison between the agricultural and energetic valorization of sewage sludge, can only be transferred to a limited extent. There is a need for further research to generally determine the agricultural benefits of hydrochar, such as increases of crop yields or carbon sequestration in the soil over a long period.

The transferability of the results of the energetic valorization concepts is also limited, since they depend on the specific setting of the HTC process and reference systems defined. The results from [42] show that the advantageousness of HTC depends on the digester gas yields, the dewatering process during the HTC, the energy consumption of the HTC plants, and the combustion efficiencies.

In addition, the advantageousness of agricultural valorization reflected in this study is not reflected in the current German practice of sewage sludge utilization. Currently, more than half of sewage sludge in Germany is incinerated, and only about on-third is agriculturally used (see Introduction). One reason for the decline in the agricultural use of sewage sludge in recent years is that the thresholds for the concentration of cadmium, lead, nickel, and mercury that were permitted in the sewage sludge became stricter in the German Sewage Sludge and Fertiliser Ordinances [66,67]. Furthermore, the German Fertilizer Application Ordinance limits the application of organic fertilizers, 
including sewage sludge, to the fields [68]. Thus, the operator of sewage treatment plants primarily focus on energy valorization, which is legally less problematic.

When considering the changing legal regulations, the results of the study can be interpreted in another way. The German Directive on Reorganization of Sludge Valorization (2017) from 27 September 2017 prescribes the phosphorus recycling for sewage treatment plants $(>100,000$ PEs) from 2029 and for sewage treatment plants ( $>50,000$ PEs) from 2032, which would no longer be possible via the direct co-combustion of sewage sludge in power plants, as the ashes would be diluted during co-combustion [69]. In addition, the direct agricultural use of sewage sludge is prohibited for these sewage treatment plants. However, sewage treatment plants of $<50,000$ PEs can still apply sewage sludge on soil. Thus, when considering the valorization of sewage sludge from sewage treatment plants $>100,000$ PEs, the first and second best concept for climate change mitigation cannot be applied from 2029 on. Assuming that the agricultural application of hydrochar will be allowed, the agricultural valorization concept A-D+HTC 1+PR is the best concept from a global warming potential perspective. If the application of hydrochar is also prohibited, the energetic valorization concepts E-SS and E-D+HTC 1+PR are the best sludge valorization options. However, it has to be mentioned that, leaving out co-combustion, will change the reference concepts and thus the GHG savings when compared to the reference.

In addition to the aspects that were investigated in this study, a number of other factors may also play a role in the decision on the integration of HTC into the concepts of valorization of sewage sludge. Some possible co-benefits of HTC are worth mentioning here, such as the degradation of organic pollutants, the removal of pathogens and helminths in the sewage sludge, and carbon sequestration in the soil, as well as the production costs that are associated with the valorization of sewage sludge.

\section{Conclusions}

The study shows that no fundamental advantage over concepts of direct agricultural and energetic valorization of sewage sludge regarding their global warming potential under the German condition are offered by integrating HTC into sewage sludge valorization concepts. The higher expenses within the HTC process cannot be compensated by additional agricultural yields and energy production. Only an optimization of the HTC process with integrated sewage sludge digestion and recirculation of the HTC process water enables comparable results. Altogether, the concept in which the sewage sludge is applied on the field after a relatively simple treatment of dewatering and digestion is the one with the highest GHG saving, and thus the most favorable concept regarding its impact on global warming. When the new requirements for valorizing sewage sludge come into effect from 2029 and 2032, neither direct agricultural use nor the direct co-combustion of sewage sludge from larger sewage treatment plants will be possible any longer in Germany. Thus, the best way to valorize sewage sludge would be to integrate a digestion of sewage sludge, as well as an optimized HTC process into the agricultural valorization concepts. Nevertheless, the agricultural valorization concepts are not generally advantageous when compared to the energetic valorization concepts, as it is shown for two concepts.

Author Contributions: Conceptualization, K.M., A.C. and C.F.; Data curation, A.C., C.F. and M.B.; Formal analysis, K.M. and A.C.; Methodology, K.M. and S.M.; Project administration, C.F.; Supervision, D.T.; Visualization, K.M.; Writing —original draft, K.M. and A.C.; Writing—-review \& editing, K.M., A.C., C.F., S.M. and D.T.

Funding: This research was funded by the Federal Ministry of Food and Agriculture (BMEL: 2815600211).

Conflicts of Interest: The authors declare no conflict of interest. The funder had no role in the design of the study; in the collection, analyses or interpretation of data; in the writing of the manuscript, or in the decision to publish the results. 


\section{References}

1. Federal Statistical Office. Environment, Waste Water Treatment-Sewage Sludge. Final Report 2013/2014. Wiesbaden, 2017. Available online: https://www.destatis.de/DE/Publikationen/ Thematisch/UmweltstatistischeErhebungen/Wasserwirtschaft/Klaerschlamm5322101139004.pdf? blob=publicationFile (accessed on 16 February 2018).

2. Funke, A.; Ziegler, F. Hydrothermal carbonization of biomass: A summary and discussion of chemical mechanisms for process engineering. Biofpr 2010, 4, 160-177. [CrossRef]

3. Libra, J.A.; Ro, K.S.; Kammann, C.; Funke, A.; Berge, N.D.; Neubauer, Y.; Titirici, M.-M.; Fühner, C.; Bens, O.; Kern, J.; et al. Hydrothermal carbonization of biomass residuals: A comparative review of the chemistry, processes and applications of wet and dry pyrolysis. Biofuels 2011, 2, 71-106. [CrossRef]

4. Berge, N.D.; Ro, K.S.; Mao, J.; Flora, J.R.V.; Chappell, M.A.; Bae, S. Hydrothermal Carbonization of Municipal Waste Streams. Environ. Sci. Technol. 2011, 45, 5696-5703. [CrossRef] [PubMed]

5. Yao, Z.; Ma, X.; Lin, Y. Effects of hydrothermal treatment temperature and residence time on characteristics and combustion behaviors of green waste. Appl. Therm. Eng. 2016, 104, 678-686. [CrossRef]

6. Zeymer, M.; Meisel, K.; Clemens, A.; Klemm, M. Technical, Economic, and Environmental Assessment of the Hydrothermal Carbonization of Green Waste. Chem. Eng. Technol. 2017, 40, 260-269. [CrossRef]

7. Mumme, J.; Eckervogt, L.; Pielert, J.; Diakité, M.; Rupp, F.; Kern, J. Hydrothermal carbonization of anaerobically digested maize silage. Bioresour. Technol. 2011, 102, 9255-9260. [CrossRef] [PubMed]

8. Reißmann, D.; Thrän, D.; Bezama, A. Hydrothermal processes as treatment paths for biogenic residues in Germany: A review of the technology, sustainability and legal aspects. J. Clean. Prod. 2018, 172, $239-252$. [CrossRef]

9. Zhao, X.; Becker, G.C.; Faweya, N.; Rodriguez Correa, C.; Yang, S.; Xie, X.; Kruse, A. Fertilizer and activated carbon production by hydrothermal carbonization of digestate. Biomass Convers. Bioref. 2018, 8, 423-436. [CrossRef]

10. Stemann, J.; Erlach, B.; Ziegler, F. Hydrothermal Carbonization of Empty Palm Oil Fruit Bunches: Laboratory Trials, Plant Simulation, Carbon Avoidance, and Economic Feasibility. Waste Biomass Valoriz. 2012, 4, 441-454. [CrossRef]

11. Basso, D.; Patuzzi, F.; Castello, D.; Baratieri, M.; Rada, E.C.; Weiss-Hortala, E.; Fiori, L. Agro-industrial waste to solid biofuel through hydrothermal carbonization. Waste Manag. 2016, 47, 114-121. [CrossRef] [PubMed]

12. Sabio, E.; Álvarez-Murillo, A.; Román, S.; Ledesma, B. Conversion of tomato-peel waste into solid fuel by hydrothermal carbonization: Influence of the processing variables. Waste Manag. 2016, 47, 122-132. [CrossRef] [PubMed]

13. Volpe, M.; Wüst, D.; Merzari, F.; Lucian, M.; Andreottola, G.; Kruse, A.; Fiori, L. One stage olive mill waste streams valorization via hydrothermal carbonization. Waste Mang. 2018, 80, 224-234. [CrossRef] [PubMed]

14. Mau, V.; Gross, A. Energy conversion and gas emissions from production and combustion of poultry-litter-derived hydrochar and biochar. Appl. Energy 2018, 213, 510-519. [CrossRef]

15. Zhang, S.; Zhu, X.; Zhou, S.; Shang, H.; Luo, J.; Tsang, D.C.W. Chapter 15-Hydrothermal Carbonization for Hydrochar Production and Its Application. In Biochar from Biomass and Waste, Fundamentals and Applications; Ok, Y.S., Tsang, D.C.W., Bolan, N., Novak, J.M., Eds.; Elsevier: Amsterdam, The Netherlands, 2019; pp. 275-294.

16. Robbiani, Z. Hydrothermal Carbonization of Biowaste/Fecal Sludge: Conception and Construction of a HTC Prototype Research Unit for Developing Countries. Master's Thesis, Swiss Federal Institute of Technology in Zurich (ETHZ), Zürich, Switzerland, 2013.

17. Danso-Boateng, E.; Holdich, R.G.; Shama, G.; Wheatley, A.D.; Sohail, M.; Martin, S.J. Kinetics of faecal biomass hydrothermal carbonisation for hydrochar production. Appl. Energy 2013, 111, 351-357. [CrossRef]

18. Parshetti, G.K.; Liu, Z.; Jain, A.; Srinivasan, M.P.; Balasubramanian, R. Hydrothermal carbonization of sewage sludge for energy production with coal. Fuel 2013, 111, 201-210. [CrossRef]

19. Namioka, T.; Morohashi, Y.; Yamane, R.; Yoshikawa, K. Hydrothermal Treatment of Dewatered Sewage Sludge Cake for Solid Fuel Production. J. Environ. Eng. 2009, 4, 68-77. [CrossRef]

20. Escala, M.; Zumbühl, T.; Koller, C.; Junge, R.; Krebs, R. Hydrothermal Carbonization as an Energy-Efficient Alternative to Established Drying Technologies for Sewage Sludge: A Feasibility Study on a Laboratory Scale. Energy Fuels 2013, 27, 454-460. [CrossRef] 
21. Zhao, P.; Shen, Y.; Ge, S.; Yoshikawa, K. Energy recycling from sewage sludge by producing solid biofuel with hydrothermal carbonization. Energy Convers. Manag. 2014, 78, 815-821. [CrossRef]

22. Wang, L.; Li, A.; Chang, Y. Relationship between enhanced dewaterability and structural properties of hydrothermal sludge after hydrothermal treatment of excess sludge. Water Res. 2017, 112, 72-82. [CrossRef] [PubMed]

23. Kruse, A.; Dahmen, N. Hydrothermal biomass conversion: Quo vadis? J. Supercrit. Fluids 2018, 134, 114-123. [CrossRef]

24. Rillig, M.C.; Wagner, M.; Salem, M.; Antunes, P.M.; George, C.; Ramke, H.-G.; Titirici, M.-M.; Antonietti, M. Material derived from hydrothermal carbonization: Effects on plant growth and arbuscular mycorrhiza. Appl. Soil Ecol. 2010, 45, 238-242. [CrossRef]

25. Qayyum, M.F.; Steffens, D.; Reisenauer, H.P.; Schubert, S. Kinetics of carbon mineralization of biochars compared with wheat straw in three soils. J. Environ. Qual. 2012, 41, 1210-1220. [CrossRef] [PubMed]

26. Kammann, C.; Ratering, S.; Eckhard, C.; Müller, C. Biochar and hydrochar effects on greenhouse gas (carbon dioxide, nitrous oxide, and methane) fluxes from soils. J. Environ. Qual. 2012, 41, 1052-1066. [CrossRef] [PubMed]

27. Busch, D.; Kammann, C.; Grünhage, L.; Müller, C. Simple biotoxicity tests for evaluation of carbonaceous soil additives: Establishment and reproducibility of four test procedures. J. Environ. Qual. 2012, 41, 1023-1032. [CrossRef] [PubMed]

28. Gajić, A.; Koch, H.-J. Sugar beet (L.) growth reduction caused by hydrochar is related to nitrogen supply. J. Environ. Qual. 2012, 41, 1067-1075. [CrossRef] [PubMed]

29. George, C.; Wagner, M.; Kücke, M.; Rillig, M.C. Divergent consequences of hydrochar in the plant-soil system: Arbuscular mycorrhiza, nodulation, plant growth and soil aggregation effects. Appl. Soil Ecol. 2012, 59, 68-72. [CrossRef]

30. Malghani, S.; Gleixner, G.; Trumbore, S.E. Chars produced by slow pyrolysis and hydrothermal carbonization vary in carbon sequestration potential and greenhouse gases emissions. Soil Biol. Biochem. 2013, 62, 137-146. [CrossRef]

31. Bargmann, I.; Rillig, M.C.; Buss, W.; Kruse, A.; Kuecke, M. Hydrochar and biochar effects on germination of spring barley. J. Agron. Crop Sci. 2013, 199, 360-373. [CrossRef]

32. Puccini, M.; Ceccarini, L.; Antichi, D.; Seggiani, M.; Tavarini, S.; Hernandez Latorre, M.; Vitolo, S. Hydrothermal Carbonization of Municipal Woody and Herbaceous Prunings: Hydrochar Valorisation as Soil Amendment and Growth Medium for Horticulture. Sustainability 2018, 10, 846. [CrossRef]

33. Melo, T.M.; Bottlinger, M.; Schulz, E.; Leandro, W.M.; de Aguiar Filho, A.M.; Wang, H.; Ok, Y.S.; Rinklebe, J. Plant and soil responses to hydrothermally converted sewage sludge (sewchar). Chemospehre 2018, 206, 338-348. [CrossRef] [PubMed]

34. Breulmann, M.; van Afferden, M.; Müller, R.A.; Schulz, E.; Fühner, C. Process conditions of pyrolysis and hydrothermal carbonization affect the potential of sewage sludge for soil carbon sequestration and amelioration. J. Anal. Appl. Pyrolysis 2017, 124, 256-265. [CrossRef]

35. Benavante, V.; Fullana, A.; Berge, N.D. Life cycle analysis of hydrothermal carbonization of olive mill waste: Comparison with current management approaches. J. Clean. Prod. 2017, 142, 2637-2648. [CrossRef]

36. Berge, N.D.; Li, L.; Flora, J.R.V.; Ro, K.S. Assessing the environmental impact of energy production from hydrochar generated via hydrothermal carbonization of food wastes. Waste Manag. 2015, 43, $203-217$. [CrossRef] [PubMed]

37. Owsianiak, M.; Ryberg, M.W.; Renz, M.; Hitzl, M.; Hauschild, M.Z. Environmental Performance of Hydrothermal Carbonization of Four Wet Biomass Waste Streams at Industry-Relevant Scales. Acs Sustain. Chem. Eng. 2016, 4, 6783-6791. [CrossRef]

38. Owsianiak, M.; Brooks, J.; Renz, M.; Laurent, A. Evaluating climate change mitigation potential of hydrochars: Compounding insights from three different Indicators. Gcb Bioenergy 2018, 10, 230-245. [CrossRef]

39. Patel, B.; Guo, M.; Izadpanah, A.; Shah, N.; Hellgardt, K. A review on hydrothermal pre-treatment technologies and environmental profiles of algal biomass processing. Bioresour. Technol. 2016, 199, 288-299. [CrossRef] [PubMed]

40. Svanström, M.; Patrick, T.N.; Fröling, M.; Peterson, A.A.; Tester, J.W. Choosing between green innovative technologies-Hydrothermal processing of biowastes. J. Adv. Oxid. Technol. 2007, 10, 177-185. 
41. Lishan, X.; Tao, L.; Yin, W.; Zhilong, Y.; Jiangfu, L. Comparative life cycle assessment of sludge management: A case study of Xiamen, China. J. Clean. Prod. 2018, 192, 354-363. [CrossRef]

42. Remy, C.; Stüber, J. Weiterentwicklung des Klima- und Ressourceneffizienzpotentials Durch HTC-Behandlung Ausgewählter Berliner Klärschlämme-HTC-Berlin; Berlin, Germany, 2015. Available online: https://www.berlin.de/senuvk/umwelt/abfall/klaerschlamm/download/HTC-BERLIN_ Abschlussbericht.pdf (accessed on 25 February 2018).

43. Schmitt, T.G.; Steinbrück, C.; Welker, A.; Dierschke, M. Perspektiven einer zukunftsfähigen Klärschlammentsorgung in Rheinland-Pfalz; Technische Universität Kaiserslautern: Kaiserslautern, Germany, 2007.

44. German Institute of Standardization. DIN EN ISO 14040 Environmental Management-Life Cycle Assessment_-Principles and Framework (ISO 14040:2006); Beuth Verlag: Berlin, Germany, 2006.

45. German Institute of Standardization. DIN EN ISO 14044 Environmental Management-Life Cycle Assessment_Requirements and Guidelines (ISO 14044:2006); Beuth Verlag: Berlin, Germany, 2006.

46. German Institute of Standardization. Sustainability Criteria for Bioenergy (ISO 13065:2015); Beuth Verlag: Berlin, Germany, 2015.

47. International Panel of Climate Change (IPCC). Climate Change 2007: The Physical Science Basis. Contribution of Working Group I to the Fourth Assessment Report of the Intergovernmental Panel on Climate Change, 2007. Available online: https://www.ipcc.ch/pdf/assessment-report/ar4/wg1/ar4_wg1_ full_report.pdf (accessed on 15 February 2018).

48. Lombardi, L.; Nocita, C.; Bettazzi, E.; Fibbi, D.; Carnevale, E. Environmental comparison of alternative treatments for sewage sludge: An Italian case study. Waste Manag. 2017, 69, 365-376. [CrossRef] [PubMed]

49. Pawelzik, P.; Carus, M.; Hotchkiss, J.; Narayan, R.; Selke, S.; Wellisch, M.; Weiss, M.; Wicke, B.; Patel, M.K. Critical aspects in the life cycle assessment (LCA) of bio-based materials-Reviewing methodologies and deriving recommendations. Resour. Conserv. Recycl. 2013, 73, 211-228. [CrossRef]

50. Klöpffer, W.; Grahl, B. Life Cycle Assessment (LCA): A Guide to Best Practice; John Wiley \& Sons: Weinheim, Germany, 2014; ISBN 3527655646.

51. Jung, J.; Von der Assen, N.; Bardow, A. Comparative LCA of multi-product processes with non-common products: A systematic approach applied to chlorine electrolysis technologies. Int. J. Life Cycle Assess. 2013, 18, 828-839. [CrossRef]

52. Ménard, J.-F.; Lesage, P.; Deschenes, L.; Samson, R. Comparative life cycle assessment of two landfill technologies for the treatment of municipal solid waste. Int. J. Lca 2004, 9, 371-378. [CrossRef]

53. Ekvall, T.; Finnveden, G. Allocation in ISO 14041-A critical review. J. Clean. Prod. 2001, 9, $197-208$. [CrossRef]

54. Finnveden, G.; Hauschild, M.Z.; Ekvall, T.; Guinée, J.B.; Heijungs, R.; Hellweg, S.; Koehler, A.; Pennington, D.; Suh, S. Recent developments in Life Cycle Assessment. J. Environ. Manag. 2009, 91, 1-21. [CrossRef] [PubMed]

55. Heijungs, R.; Guinée, J.B. Allocation and 'what-if' scenarios in life cycle assessment of waste management systems. Waste Manag. 2007, 27, 997-1005. [CrossRef] [PubMed]

56. Weidema, B. Avoiding Co-Product Allocation in Life-Cycle Assessment. J. Ind. Ecol. 2001, 4, 11-33. [CrossRef]

57. Fleischer, G.; Schmidt, W.-P. Functional unit for systems using natural raw material. Int. J. Lca 1996, 1, $23-27$. [CrossRef]

58. Arbeitsgemeinschaft für Sparsamen und Umweltfreundlichen Energieverbrauch e.V. (ASUE). BHKW-Kenndaten 2014/2015. Berlin, 2014. Available online: https://asue.de/sites/default/files/ asue/themen/blockheizkraftwerke/2014/broschueren/05_10_14_bhkw_kenndaten_leseprobe.pdf (accessed on 3 February 2018).

59. Haberkern, B.; Maier, B.; Schneider, U. Steigerung der Energieeffizienz auf Kommunalen Kläranlagen. Dessau-Roßlau, 2008. Available online: https://www.umweltbundesamt.de/sites/default/files/medien/ publikation/long/3347.pdf (accessed on 15 February 2018).

60. Obernberger, I.; Thek, G. Combustion and gasification of solid biomass for heat and power production in Europe - State-of-the-art and relevant future developments. In Proceedings of the 8th European Conference on Industrial Furnaces and Boilers, Dom Pedro Golf Resort, Vilamoura, 25-28 March 2008.

61. Füller, M. Energie aus dem Nordosten; Vattenfall Europe Mining \& Generation: Cottbus, Germany, 2006.

62. Ifu Hamburg GmbH. Umberto NXT Universal 7.1.13 Software; Ifu Hamburg GmbH: Hamburg, Germany, 2017. 
63. Ecoinvent Association. Ecoinvent v2.2; Swiss Federal Institute of Technology (ETH): Zurich, Switzerland, 2010.

64. Ecoinvent Association. Ecoinvent v3.3; Swiss Federal Institute of Technology (ETH): Zurich, Switzerland, 2016.

65. International Institute for Sustainability Analysis and Strategy (IINAS). GEMIS-Global Emissions Modell for Integrated Systems v4.9; International Institute for Sustainability Analysis and Strategy (IINAS): Darmstadt, Germany, 2014.

66. Verordnung über die Verwertung von Klärschlamm, Klärschlammgemisch und Klärschlammkompost (Klärschlammverordnung-AbfKlärV) from 27.09.2017. Available online: https:/ / www.gesetze-im-internet. de/abfkl_rv_2017/AbfKl\%C3\%A4rV.pdf (accessed on 16 February 2018).

67. Verordnung über das Inverkehrbringen von Düngemitteln, Bodenhilfsstoffen, Kultursubstraten und Pflanzenhilfsmitteln (Düngemittelverordnung-DüMV) from 26.05.2017. Available online: https://www. gesetze-im-internet.de/d_mv_2012/DüMV.pdf (accessed on 16 February 2018).

68. Verordnung über die Anwendung von Düngemitteln, Bodenhilfsstoffen, Kultursubstraten und Pflanzenhilfsmitteln nach den Grundsätzen der Guten Fachlichen Praxis beim Düngen (Düngeverordnung-DüV) from 26.05.2017. Available online: https://www.gesetze-im-internet. de/d_v_2017/DüV.pdf (accessed on 3 February 2019).

69. Directive on Reorganization of Sludge Valorization from 27.09.2017. Available online: https: / / www.bgbl.de / xaver/bgbl/start.xav?startbk=Bundesanzeiger_BGBl\&start=\%2F\%2F\%2A\%5B \% 40attr_id=\%27bgbl117s3465.pdf\%27\%5D\#_bgbl_\%2F\%2F*\%5B\%40attr_id\%3D\%27bgbl117s3465.pdf\% 27\%5D_1549402355053 (accessed on 3 February 2019).

(C) 2019 by the authors. Licensee MDPI, Basel, Switzerland. This article is an open access article distributed under the terms and conditions of the Creative Commons Attribution (CC BY) license (http:/ / creativecommons.org/licenses/by/4.0/). 